\title{
International conjoint STD meeting and 32nd General Assembly of the International Union against the Venereal Diseases and Treponematoses
}

\author{
Report on the international conjoint meeting on sexually transmitted diseases held on 17-21 June 1984 in \\ Montreal, Canada
}

\begin{abstract}
An international conjoint meeting on sexually transmitted disease (STD) in association with the 32nd General Assembly of the International Union against the Venereal Diseases and Treponematoses (IUVDT) was held in Montreal on 17-21 June 1984. The conference took place in the Queen Elizabeth Hotel, where the facilities were excellent. Just over 1000 participants were present.
\end{abstract}

The meeting had been carefully organised by Dr Richard Morisset and his organising committee. It consisted of a series of plenary sessions with several periods devoted to free communications. There were excellent poster sessions and some well attended refresher periods for practitioners.

Speakers kept to their allotted times, and the simultaneous translation in English and French was of high standard. Inevitably there were several disturbing episodes when the projection facilities broke down, the wrong slides were projected, or slides were projected upside down. It still seems to be beyond the ability of conference organisers, projectionists, and speakers to arrange for visual aids to function correctly; and failure to show slides without fuss or error is an unnecessary cause of irritation and loss of

Address for reprints: Dr R D Catterall, 61 Durrels House, Warwick Gardens, London W14 8QB

Accepted for publication 12 September 1984 concentration. Much more attention should be given to this important matter by both conference organisers and speakers.

The early sessions concentrated on the acquired immune deficiency syndrome (AIDS), and excellent reviews of current knowledge and opinion on the subject were presented by Dr Walter Dowdle, Director of the Centre for Infectious Diseases, Centers for Disease Control, Atlanta, Dr Harold Jaffe, Dr Antony Fauci, and Dr Robert Gallo. The highlight of the session was a paper by Dr Luc Montagnier from the Department of Viral Oncology at the Pasteur Institut in Paris, in which he described the isolation of a lymphotropic retrovirus derived from $\mathrm{T}$ lymphocytes in patients with AIDS and persistent lymphadenopathy. Antibodies against this virus have been shown in serum from patients with the disease, and suggest that the virus is probably transmitted in blood and blood products and by sexual contact.

The Grand Salon was packed for these papers, and a lively and far reaching discussion took place. Other important sessions on genital ulceration, vaginitis hepatitis B, chlamydiae, gonorrhoea, and herpes also drew large numbers of participants. Great interest was also shown in the sessions on the complications of genital infection in women, especially in developing countries.
A session on the global impact of STD was addressed by Dr George Causse of the World Health Organisation, $\mathrm{Dr}$ King Holmes, Dr André Meheus, and Dr Donald Hopkins.

There is no doubt that the highlight of this conference was the description of and discussion about the agent probably responsible for AIDS. This retrovirus has a long incubation period, is spread by blood products, and produces immunosuppression. It is, however, not yet completely proved that it is the cause of AIDS, although the existing evidence points clearly in that direction.

The scientific aspects of the meeting were very successful, as was the 32 nd general assembly of the IUVDT. The American Venereal Disease Association also held its executive board meeting in Montreal. There was a reception at the University of Montreal, a wine and cheese party in the Botanical Gardens, a banquet in the Grand Salon of the Queen Elizabeth Hotel, and a visit to Quebec City at the end of the conference. This meeting will be regarded as one of the major conferences on STD, and those who took part in it will remember the apparently effortless way in which $\mathrm{Dr}$ Morisset and his colleagues planned and carried out the complex organisation.

Vive le Canada unis! $R D$ Catterall Vice President. IUVDT 